\title{
Michael Behe. The edge of evolution: the search for the limits of darwinism
}

\author{
Gabriel da Costa Ávila*
}

New York: Free Press, 2007. 331p.

A teoria da evolução a partir de um ancestral comum, através da seleção natural e da mutação aleatória, exposta por Charles Darwin n'A origem das espécies em $1859,{ }^{1}$ formou um dos conjuntos de idéias mais influentes na história recente da ciência. $\mathrm{O}$ darwinismo atravessou as barreiras da academia e difundiu-se, bastante matizado, pela sociedade. Durante quase um século, o darwinismo dominou a explicação científica da origem da vida.

Com as novas descobertas ocorridas a partir de meados do século passado, especialmente do DNA, o nível de complexidade por trás dos processos celulares se mostrou maior do que o esperado pelos evolucionistas. Pôr o darwinismo à prova, à luz dessas descobertas, abre um enorme espaço para a refutação das idéias do naturalista inglês. Atualmente, o questionamento mais vigoroso a respeito da validade dos fundamentos teóricos do darwinismo parte das críticas de Michael Behe.

Michael J. Behe é um autor conhecido entre os estudiosos do darwinismo. Bioquímico e professor na Leigh University, na Pensilvânia, Estados Unidos, popularizou-se por defender o criacionismo - bastante camuflado - de forma bastante competente. Em 1996, com o lançamento de A caixa preta de Darwin, ${ }^{2}$ o autor tentava provar que algumas estruturas bioquímicas presentes em certas células são tão complexas que não podem ser explicadas pelo argumento da mutação aleatória, contrariando um dos pilares do darwinismo. A análise de Michael Behe fez o autor figurar entre os principais cientistas a advogarem em prol da teoria do design inteligente. Essa teoria defende que o darwinismo, mesmo sendo bastante coerente e verossímil, é insuficiente para a compreensão da vida e da evolução: a vida na Terra não alcançaria o estágio que alcançou ba-

\footnotetext{
* Mestrando em Ensino, Filosofia e História das Ciências - Universidade Estadual de Feira de Santana; FFCH - Depto. de História, Universidade Federal da Bahia (UFBA) - Estrada de São Lázaro, 197 - Federação. 40210-730 Salvador - BA - Brasil. gabriel_avila_00@hotmail.com.
} 
seada apenas em processos aleatórios. É necessário que haja um caminho a seguir, um projeto, um design funcional a ser alcançado.

Um dos suportes teóricos fundamentais para o design inteligente é o conceito de complexidade irredutível, introduzido por Behe em A caixa preta de Darwin. Segundo o autor, os avanços da ciência nos permitiram questionar a proposta evolutiva de Charles Darwin, principalmente quando se dispõe de dados e informações a que o naturalista jamais teve acesso, notadamente no que diz respeito à genética e à bioquímica. Analisando algumas estruturas celulares especialmente 'elegantes', o autor afirma que estas possuem uma configuração tão sofisticada que se torna impossível concebê-las em estágios anteriores na evolução, isto é, essas estruturas não poderiam ter evoluído de nada mais simples sem ter suas funções irremediavelmente comprometidas. Isso as faz irredutivelmente complexas. O livro gerou polêmica não apenas por seu conteúdo, mas também pela forma convincente da exposição.

Um longo debate teve início. Os darwinistas atacavam acusando os adeptos do design inteligente de criacionistas e anticientificistas, uma vez que, posta a questão do projeto que guia a evolução, é fácil questionar também a respeito do projetista. Quem é o designer? E a pergunta transcende o reino da razão, no qual se estabeleceu a ciência moderna, e passa para o campo metafísico da crença e da religião. Mesmo que se prove a inconsistência do darwinismo para explicar o desenvolvimento bioquímico de alguns organismos, o que é bastante saudável no meio acadêmico - embora o darwinismo possua acólitos fervorosos - , a hipótese de uma inteligência por detrás das estruturas da natureza lembra demais o criacionismo e outras idéias que não se sustentam se postas à prova pelos métodos desenvolvidos pela ciência para testar o conhecimento que ela produz.

Os defensores do design inteligente, por sua vez, acusavam os evolucionistas darwinistas de dogmatismo e de censura ao desenvolvimento científico, sentiam-se perseguidos por cientistas que se recusavam a aceitar a possibilidade de uma nova teoria para a evolução, julgavam estar enfrentando a "Nomenklatura científica". ${ }^{3}$

Fica claro no debate a tentativa, de ambas as 'facções', de desqualificar os argumentos dos 'adversários' empurrando-os para o terreno da não-ciência, ou, ao menos, da 'má ciência'.

Mais de dez anos depois de publicado o livro que reacendeu a tensão entre darwinistas e adeptos do design inteligente, Michael Behe volta à carga com The edge of evolution: a search for the limits of darwinism, estudo, lançado em 2007 e ainda sem tradução em português, que aprofunda as conclusões obtidas em A caixa preta de Darwin. 
Enquanto o livro de estréia do autor partia de uma investigação mais específica, a respeito da 'complexidade irredutível' de algumas estruturas bioquímicas sofisticadas, The edge of evolution é muito mais ambicioso. A idéia central do livro é desenhar linhas gerais que demarquem o terreno a partir do qual o darwinismo deixa de ser útil na explicação não apenas de alguns processos bioquímicos localizados, mas também de aspectos gerais da origem das espécies. Com isso, o velho criacionismo ganha um status de saber científico na figura do design inteligente e, assim, pode disputar com o darwinismo o papel de detentor do conhecimento acerca da origem das espécies e da vida. Não é, agora, uma questão de 'ciência contra religião', mas sim de teorias científicas concorrentes.

Para os estudiosos da ciência, o surgimento de teorias que usem os pressupostos do racionalismo científico a partir de um pano de fundo religioso é, no mínimo, intrigante, pois aponta para questões novas que exigem uma revisão acerca das tradicionais idéias de ciência e razão. O desencantamento do mundo e a substituição dos elementos mágicos por elementos racionais que, para Max Weber, consistia numa das principais características da modernidade 4 - parece subvertido de forma bastante sofisticada. A razão científica é invocada por Michael Behe para dar validade a uma concepção mágica do mundo.

O estudo de Behe tem o mérito de investigar, como indica o título, os limites do darwinismo. Contudo, embora suas pesquisas demonstrem os pontos frágeis do darwinismo, não apresentam nenhuma evidência relevante a favor do design inteligente. Cabe a nós, historiadores e estudiosos da ciência, perguntarmo-nos que motivos o levaram a extrapolar de forma tão radical as fronteiras do método científico na defesa de sua teoria, quando, ao mesmo tempo, defende esse método tão veementemente ao atacar o darwinismo. De resto, é necessário atentarmos para a possível emergência de uma nova relação entre ciência e religião.

Uma história do darwinismo que tenha a pretensão de compreender o território conflituoso da afirmação de uma teoria científica em sua dimensão social não pode perder de vista as condições socioculturais que envolvem a produção dos discursos científicos. Ou seja, deve-se refletir sobre o tipo de ciência que pode ser feita por um católico apostólico romano que, como Michael Behe, direciona seu discurso a partir de convicções filosóficas e religiosas.

Não se trata de considerar, no entanto, a ciência como uma atividade neutra, objetiva, que pode ser corrompida pela subjetividade de criacionistas com interesses espúrios; trata-se de perceber a ciência como uma atividade humana que se inscreve no âmbito da cultura e que, por isso, está sujeita a 
variações e condicionantes sociais, culturais e históricos. A ciência está imersa em seu tempo. E o caso de Behe aponta para isso.

$\mathrm{O}$ design inteligente, como formulado por esse autor, dá aos criacionistas uma excelente oportunidade de desafiar o darwinismo na interpretação da origem da vida em igualdade de condições, especialmente em relação ao ensino dessas teorias nas escolas públicas dos Estados Unidos. Lá, a disputa pelo ensino do criacionismo em substituição, ou em paralelo, ao evolucionismo remonta ao início do século passado, e a matéria acabou na justiça em 1987, quando se decidiu suprimir o ensino do criacionismo, com base na noção de Estado laico. Com o advento do design inteligente, porém, a situação se altera.

Graças ao esforço cientificista de Michael Behe e outros cientistas ligados a essa corrente, outra vez a peleja entre darwinistas e criacionistas, agora escudados pelo design inteligente, vem à baila. Em 2004, a tentativa, no Liceu de Dover, de introduzir o design inteligente como explicação alternativa à origem da vida resultou em novo processo judicial, no qual a instituição foi acusada de privilegiar interpretações religiosas, contrariando assim o laicismo que rege a educação nos Estados Unidos. Pode-se perceber um jogo político no qual a ciência é um cavalo de batalha. E a reconfiguração do alcance do darwinismo, seja nas suas lacunas bioquímicas, seja nas cartilhas escolares, não significa um avanço das trevas sobre os territórios das luzes e da razão, mas uma demonstração da dinâmica da ciência tal qual se faz.

\section{NOTAS}

${ }^{1}$ DARWIN, Charles. On the origin of species. Cambridge: Harvard University Press, 1975. $512 \mathrm{p}$.

${ }^{2}$ Cf. BEHE, Michael. A caixa preta de Darwin: o desafio da bioquímica à teoria da evolução. Trad. Ruy Jungmann. 1.ed. Rio de Janeiro: Jorge Zahar, 1997. 300p.

${ }^{3}$ A Nomenklatura era a classe dirigente soviética, composta pelo alto escalão do partido comunista e do Estado. Segundo alguns críticos do regime de Moscou era o próprio Estado e usava essa condição para se beneficiar. É usada por alguns autores que defendem o design inteligente, quando se referem aos darwinistas, que dispõem de prestígio nas instituições científicas e constituiriam uma classe privilegiada.

${ }^{4}$ WEBER, Max. A ética protestante e o espírito do capitalismo. Trad. José Marcos Mariani Macedo. 1.ed. São Paulo: Companhia das Letras, 2004. 336p.

Resenha recebida em agosto de 2008. Aprovada em setembro de 2008. 